\title{
Silver nanoparticles in orthodontics, a new alternative in bacterial inhibition: in vitro study
}

\author{
Irania Jasso-Ruiz', Ulises Velazquez-Enriquez ${ }^{2 *}$ (D), Rogelio José Scougall-Vilchis², Raúl Alberto Morales-Luckie ${ }^{3}$, \\ Toshiko Sawada ${ }^{4}$ and Ryozo Yamaguchi ${ }^{5}$
}

\begin{abstract}
Background: The purpose of the study is to assess the antiadherent and antibacterial properties of surfacemodified different orthodontic brackets with silver nanoparticles against Streptococcus mutans and Streptococcus sobrinus, using radiomarker.
\end{abstract}

Methods: In this study evaluated quantitatively the adherence of Streptococci to orthodontic brackets, 300 samples of orthodontic brackets were selected and classified in to 10 groups as follow: Gln (InVu-Roth), Glln (SystemAlexanderLTS), GIlln (Gemini-Roth), GIVn (NuEdge-Roth), GVn (Radiance plus-Roth), GVI (InVu-Roth), GVII (SystemAlexanderLTS), GVIII (Gemini-Roth), GIX (NuEdge-Roth), GX (Radiance plus-Roth). All the samples were sonicated and Streptococci were cultivated by gender. A radioactive marker $\left({ }^{3} \mathrm{H}\right)$ was used to codify the bacteria and measure them. After that, the brackets were submerged in a radiolabelled solution, and the radiation was measured. The statistical analysis was calculated with ANOVA test (Sheffè post hoc).

Results: The results showed significant differences were found among the groups. Gllln shown the lowest scores for both bacteria; in contrast, GIX for Streptococcus mutans and GVI for Streptococcus sobrinus were the highest values.

Conclusions: Surface modification of orthodontic brackets with silver nanoparticles can be used to prevent the accumulation of dental plaque and the development of dental caries during orthodontic treatment.

Keywords: Orthodontic brackets, Streptococcus mutans, Streptococcus sobrinus, Silver nanoparticles, White spot lesion

\section{Background}

The oral cavity environment provides certain essential characteristics for the proliferation of bacteria that are capable of producing acids that demineralize the surface of the tooth enamel [1]. Biofilm has a crucial role in the adhesion of these microorganisms to the dental surface $[2,3]$. Enamel demineralization is caused by the organic acids produced by various microorganisms, mainly

\footnotetext{
* Correspondence: uvelazqueze@uaemex.mx

${ }^{2}$ Department of Orthodontics, School of Dentistry, Autonomous University State of Mexico, Paseo Tollocan esq. Jesús Carranza S/N, Universidad, 50130 Toluca City, México

Full list of author information is available at the end of the article
}

Streptococcus mutans (S. mutans) and Streptococcus sobrinus (S. sobrinus), which are identified as the main pathogens in dental caries [4-7].

Dental caries has been defined by the World Health Organization (WHO) as a localized process of multifactorial origin; this begins as a demineralization, which is the softening of the hard tissue of the tooth and evolves into the formation of a cavity. WHO reports that there is a prevalence in $60 \%$ to $90 \%$ of school children and almost $100 \%$ of adults have dental caries around the world, coinciding with the Official Mexican Standard 013 report, where it is mentioned that there is a $90 \%$ prevalence in Mexico [8].

\section{Springer Open}

(c) The Author(s). 2020 Open Access This article is licensed under a Creative Commons Attribution 4.0 International License, which permits use, sharing, adaptation, distribution and reproduction in any medium or format, as long as you give appropriate credit to the original author(s) and the source, provide a link to the Creative Commons licence, and indicate if changes were made. The images or other third party material in this article are included in the article's Creative Commons licence, unless indicated otherwise in a credit line to the material. If material is not included in the article's Creative Commons licence and your intended use is not permitted by statutory regulation or exceeds the permitted use, you will need to obtain permission directly from the copyright holder. To view a copy of this licence, visit http://creativecommons.org/licenses/by/4.0/. 
Orthodontic treatment, using fixed appliances (brackets, bands, archwires, ties), provides suitable conditions to bring about the colonization of cariogenic microorganisms. Because fixed appliances promote the retention and adhesion of biofilm, dental hygiene becomes more complicated, and microorganisms increase the risk of enamel demineralization $[4,5]$.

Since 1985, the scientific community has been very concerned about the interaction between orthodontic devices and oral bacteria [9, 10]. In 2012, Freitas et al. concluded moderate evidence that the presence of fixed appliances influences the quantity and quality of oral microbiota [11]. Moreover, Luchese et al., in their research, report that orthodontic appliances influence the oral microbiota with an increase in the counts of $S$. mutans and Lactobacillus spp. and in the percentage of potentially pathogenic gram-negative bacteria [12].

It has been claimed that 50 to $70 \%$ of patients undergoing fixed orthodontic appliance therapy had enamel demineralization around the brackets (white spot lesions or cavities) $[4,5]$. This has been widely known from the first month after the brackets placement, ranging from 12.6 to $50 \%$ [13-17].

The oral $\mathrm{pH}$ levels and various microorganisms normally present in the oral cavity may influence the adhesion capacity of bacteria, a formation of biofilm, which increases the risk of demineralization in enamel, and caries development, particularly the bracket material [18].

Electrostatic and hydrophobic interactions mostly cause the first affinity of bacteria to solid surfaces. Surfaces with high free energy attract bacteria, such as $S$. mutans, more easily [18]. In a study by Eliades et al. [19], stainless steel presented the highest critical surface tension and can be expected to have a higher plaqueretaining capacity. Metallic orthodontic brackets have been found to induce specific changes in the oral environment, such as reduced levels of $\mathrm{pH}$, increased plaque accumulation, and elevated S. mutans and S. sobrinus colonization. Nevertheless, recent studies on possible differences in the initial affinity and adherence of bacteria on metal, ceramic, and plastic brackets over time were inconclusive $[1,19,20]$.

The prevention of white spot lesions, caries, and periodontal problems during orthodontic treatment is a significant challenge to the clinician and the patient. Many strategies have been proposed and developed to minimize these biological consequences, which may include fluoride varnishes or mousses, various toothpastes, and mouth rinses $[19,21]$. Unfortunately, only less than $15 \%$ of orthodontic patients follow instructions [22-24].

Besides that with the emergence of an antibioticresistant strain of bacteria, certain metals particularly in nanoparticle form have attracted attention.
Nanoparticles are insoluble particles having a size smaller than $100 \mathrm{~nm}$ and can be used either combining with dental materials or by coating the surface which aims to reduce the microbial adhesion and prevent caries [14].

Among the various metals, silver since ages is known for its antimicrobial activity against gram-positive and negative bacteria, fungi, protozoa, and certain viruses, including antibiotic-resistant strains. Because of these properties, silver is widely used in burned areas, medical devices, textile fabric, and as a water purifier [25]. Surface coating of silver can be obtained by different methods, chemistry, physical, and biological [26].

The silver nanoparticles (AgNPs) have been added to conventional orthodontic adhesives and appliances, the critical issue is that the physical and chemical properties should not be affected adversely, leading to the ideal clinical performance. Further, the antimicrobial and antiadhesive properties, as well as the safety of the new nanoadhesives, must be ensured over a clinically relevant time span [27, 28].

As it has been found in the scientific literature, the studies on the use of AgNPs is limited [28-32]. It is for this reason that the purpose of this investigation was to determine and compare the independent bacterial colonization of $S$. mutans and $S$. sobrinus in five different types of orthodontic bracket materials, as well as to verify the effectiveness of the incorporation of AgNPs in some of them.

\section{Methods}

\section{Orthodontic brackets}

A total of 300 commercial orthodontic brackets were used ( $n=30$ per group) and classified into 10 groups of orthodontic brackets (5 groups with silver nanoparticles and 5 groups without silver nanoparticles) of the different material as follows: GIn InVu Roth, (TP Orthodontics, LaPorte, Ind., USA), GIIn System Alexander LTS (AO. American Orthodontics, Wisconsin., EE. UU), GIIIn Gemini Roth (3 M Unitek, Monrovia, CA., USA), GIVn Nu-Edge Roth (TP Orthodontics, LaPorte, IN, USA), GVn Radiance plus Roth (AO. American Orthodontics, Wisconsin., EE. UU), GVI InVu Roth (TP Orthodontics, LaPorte, IN, USA), GVII System Alexander LTS (AO. American Orthodontics, Wisconsin., EE. UU), GVIII Gemini Roth (3 M Unitek, Monrovia, CA, USA), GIX Nu-Edge Roth (TP Orthodontics, LaPorte, IN, USA), GX Radiance plus Roth (AO. American Orthodontics, Wisconsin., EE. UU).

\section{Preparation of samples}

There is a total of 300 orthodontic brackets (150 brackets for S. mutans, 150 brackets for S. sobrinus); all the samples were initially cleaned ultrasonically for a 
minute to eliminate impurities and were then dried. Only half of the samples from each group that does not have silver nanoparticles were sterilized with ethylene oxide gas, the other half of the samples have silver nanoparticles (AgNPs). To avoid contamination, the samples were stored in a humidity-free environment.

\section{Radiolabeled bacteria and culture conditions}

S. mutans ATCC25175 and S. sobrinus ATCC33478 were maintained as frozen stock cultures and were cultured anaerobically at $37^{\circ} \mathrm{C}$ in a solid trypticase soy broth (BBL, Cockeysville, MD, USA), yeast extract (Difco Laboratories, Detroit, MI, USA), and agar for $18 \mathrm{~h}$. Afterward, the microorganisms were inoculated in 150$\mathrm{ml}$ liquid TSBY for $18 \mathrm{~h}$ and were then anaerobically inoculated separately from the $150 \mathrm{ml}$ of liquid TSBY with a radioactive marker, $74 \mathrm{kBq}$ of $\left[6-{ }^{3} \mathrm{H}\right]$ thymidine, used to codify the microorganism and cultured for $18 \mathrm{~h}$ at $37^{\circ} \mathrm{C}$. Next, bacteria were collected through centrifugation of $8000 \times \mathrm{g}$ for $15 \mathrm{~min}$ at $4{ }^{\circ} \mathrm{C}$ into $0.05 \mathrm{M}$ phosphatebuffered saline (PBS) adjusted to $\mathrm{pH} 7.0$ and washed three times with PBS. The concentration of $S$. mutans and $S$. sobrinus was $105 \mathrm{CFU} / \mathrm{ml}$.

\section{Sample analysis}

The orthodontic brackets were dispersed from the cap of a glass mold and immersed in $150 \mathrm{ml}$ of S. mutans (150 brackets) and S. sobrinus (150 brackets) radiolabeled fluid, respectively, at $37^{\circ} \mathrm{C}$ for $2 \mathrm{~h}$ in constant movement. To remove the non-adhering bacteria, the brackets were removed from the glass mold and washed three times with PBS.

The labeled bacteria that adhered to the brackets were collected using an automatic sample combustion equipment (ACS-113, Aloka, Tokyo, Japan). Tritium was recovered as $\mathrm{H}_{2} \mathrm{O}$ in Aquasol-2 (Packard), and radioactivity was measured using a liquid scintillation counter (LSC-900, Aloka) [33-35]. The results were recorded as disintegration per minute $(\mathrm{dpm})$; therefore, the average of higher radiation level was proportional to the higher level of bacterial colonization.

In addition, after submerging the specimens for $2 \mathrm{~h}$ at $37^{\circ} \mathrm{C}$ in a solution containing cultured microorganisms with continuous stirring, some representative samples were observed under a scanning electron microscope $(\mathrm{SEM})$ at $\times 2500$ and $\times 5000$ magnifications for qualitative analysis. For the SEM observation, the samples were chemically prefixed with glutaraldehyde and fixed with osmium tetroxide, dehydrated with an ascending series of ethanol, and freeze-dried. The samples were coated with a thin layer of osmium $[20,24,36]$.

\section{Statistical analysis}

The data were registered and examined using a software for statistical analyses (SPSS 21, International Business Machines Corp, NY, USA). The differences in the measured values among the orthodontic brackets were tested by one-way analysis of variance (ANOVA) with a Scheffé test for multiple comparisons. A probability of less than 0.05 for similarity of distribution was considered to be statistically significant.

\section{Results}

\section{Adhesion of Streptococcus mutans}

The adherence of $S$. mutans radiolabeled to orthodontic brackets were significantly different between the groups $(p \leq 0.05)$. The scores were expressed as $\mathrm{dpm}$ as shown in Table 1. The dpm values, orthodontic brackets with greater adhesion of $S$. mutans were labeled as group GVI (3153.83 dpm), followed by group GVIII (2203.94 $\mathrm{dpm})$, and finally group GIX (2186.23 dpm), silver nanoparticles are not added to these groups. Moreover, the groups with the lowest bacterial adherence were those with a coaggregation of silver nanoparticles; these groups are as follows: group GVn $(687.33 \mathrm{dpm})$, followed by group GIIn (599.13 dpm), and group GIIIn (563.01 dpm).

\section{Adhesion of Streptococcus sobrinus}

The adherence of $S$. sobrinus radiolabeled to orthodontic brackets were significantly different between the groups $(p \leq 0.05)$. The scores were expressed as dpm as shown in Table 2. For the dpm values, the orthodontic brackets with greater adhesion of $S$. sobrinus were grouped as follows: group GIX (8197.32 dpm), group GVIII (7518.39 $\mathrm{dpm})$, and group GVI (7256.29 dpm), silver nanoparticles are not added to these groups. Moreover, the groups with the lowest bacterial adherence were those with a

Table 1 Quantitative test to S. mutans by radiolabeled $\left({ }^{3} \mathrm{H}\right)$

\begin{tabular}{llll}
\hline Bracket & DPM $^{\text {a }}$ & SD $^{\text {b }}$ & Sheffè test $^{c}$ \\
\hline Gln In Vu Ag & 707.78 & $(265.29)$ & A \\
Glln Alexander Ag & 599.13 & $(260.85)$ & A \\
GIIIn Gemini Ag & 563.01 & $(287.71)$ & B \\
GIVn Nu-Edge Ag & 775.39 & $(520.47)$ & B \\
GVn Radiance Ag & 687.33 & $(284.24)$ & B \\
GVI In Vu & 3153.83 & $(1071.06)$ & $\mathrm{C}$ \\
GVII Alexander & 2044.00 & $(904.52)$ & D \\
GVIII Gemini & 2203.94 & $(868.32)$ & C \\
GIX Nu-Edge & 2186.23 & $(568.11)$ & $C$ \\
GX Radiance & 1714.01 & $(375.42)$ & C, D \\
\hline
\end{tabular}

${ }^{\mathrm{a} D P M}$ (disintegration per minute)

${ }^{\mathrm{b}} \mathrm{SD}$ (standard deviation)

'Orthodontic brackets with different letters are significantly different from each other 
Table 2 Quantitative test to S. sobrinus by radiolabeled $\left({ }^{3} \mathrm{H}\right)$

\begin{tabular}{llll}
\hline Bracket & DPM $^{\mathrm{a}}$ & SD $^{\mathrm{b}}$ & Sheffè test $^{\mathrm{c}}$ \\
\hline GIn In Vu Ag & 1906.48 & $(1037.91)$ & A \\
Glln Alexander Ag & 1513.64 & $(882.12)$ & $\mathrm{A}$ \\
GIIIn Gemini Ag & 1044.08 & $(415.86)$ & B, C \\
GIVn Nu-Edge Ag & 1084.31 & $(415.44)$ & B, C \\
GVn Radiance Ag & 1085.67 & $(303.03)$ & B, C \\
GVI In Vu & 7256.29 & $(1421.48)$ & D \\
GVII Alexander & 5457.09 & $(1550.05)$ & E \\
GVIII Gemini & 7518.39 & $(1494.52)$ & D \\
GIX Nu-Edge & 8197.32 & $(2174.98)$ & D \\
GX Radiance & 6660.28 & $(1436.74)$ & D,E \\
\hline
\end{tabular}

${ }^{a} D P M$ (disintegration per minute)

${ }^{\mathrm{b}} \mathrm{SD}$ (standard deviation)

'Orthodontic brackets with different letters are significantly different from each other

coaggregation of silver nanoparticles; the groups were as follows: group GVn (1085.67 dpm), group GIVn (1084.31 dpm), and group GIIIn (1044.08 dpm).

The representative SEM images of the brackets materials obtained after $2 \mathrm{~h}$ of immersion in $S$. mutans and $S$. sobrinus solutions are shown in Figs. 1 and 2. The results obtained in the quantitative analysis are consistent with the qualitative observation in SEM.

According to the dpm values, for all the bracket groups with added silver nanoparticles (AgNPs), the bacterial adherence of both microorganisms was lower than that in the groups of brackets without the addition of silver nanoparticles.

\section{Discussion}

White spot lesions are associated with enamel demineralization around fixed orthodontic appliances. Orthodontic appliances have a leading role in the demineralization of enamel because they provide greater retention of biofilm, providing more surfaces for bacterial adhesion, and its complex design prevents adequate tooth surface during cleaning [20,32, 36]. Several species of bacteria are involved in the formation of dental biofilm, and white spots lesions caused by organic acids that secrete cariogenic bacteria. Among them, S. mutans and $S$. sobrinus have been recognized as the prime causative organisms of dental caries [2]. Gorelick reported that enamel demineralization occurs from the first month after the placement of fixed appliances, and it is estimated that the prevalence of white spot injury in the enamel of orthodontically treated patients ranges from 12.6 to $50 \%$ [16, 17].

Limited information is available on which orthodontic bracket are most susceptible to adhesion of cariogenic streptococcus. Streptococcus mutans and Streptococcus sobrinus are mainly responsible for dental caries. Because the popularity of plastic brackets has grown during the last few years due to increased demand for superior
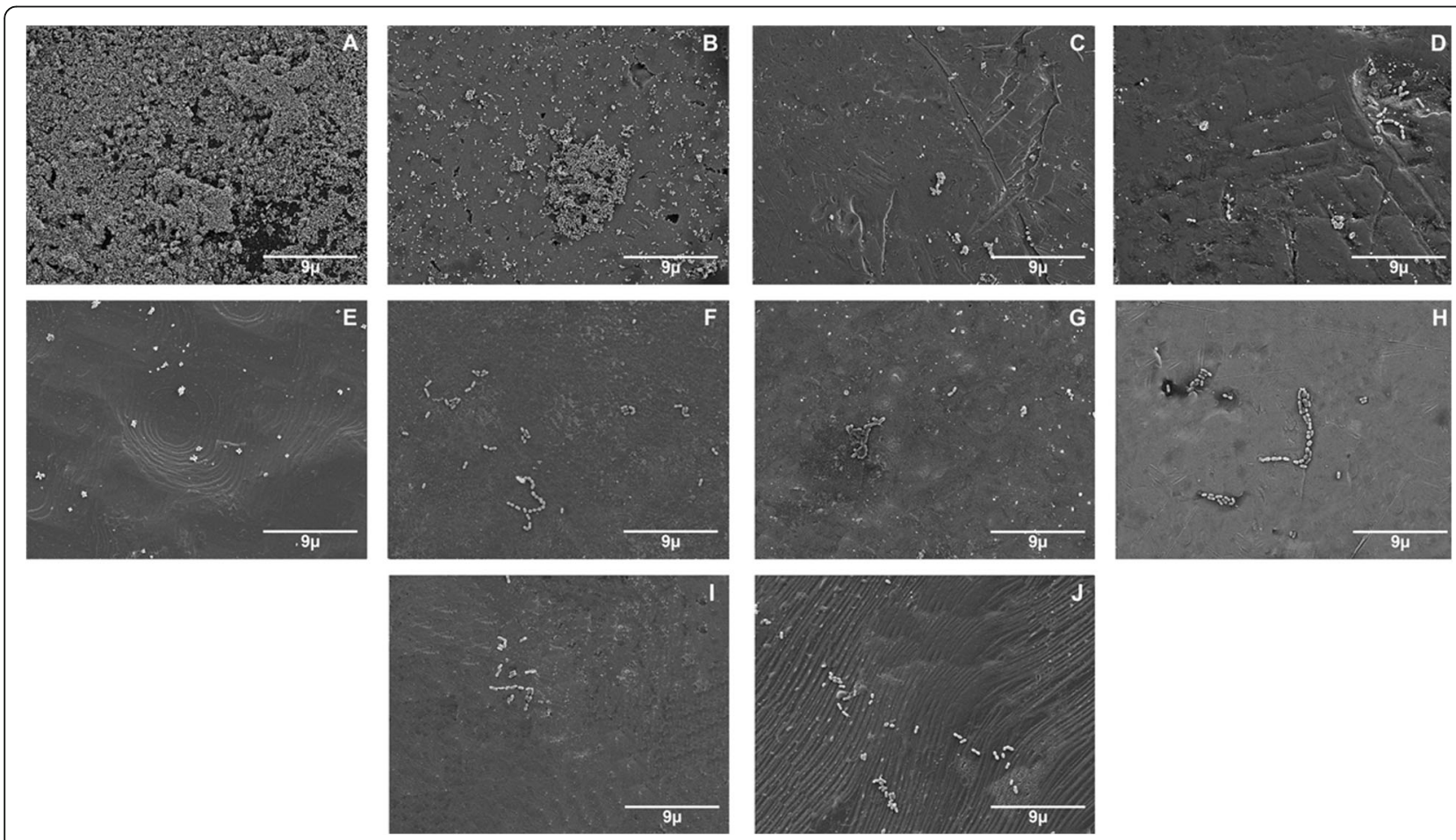

Fig. 1 Representative images from SEM of orthodontic brackets exposed to S.mutans (×2500). a Gln. b GIIn. c GIIIn. d GIVn. e GVn. f GVI. g GVII. h GVIII. i GIX. j GX 

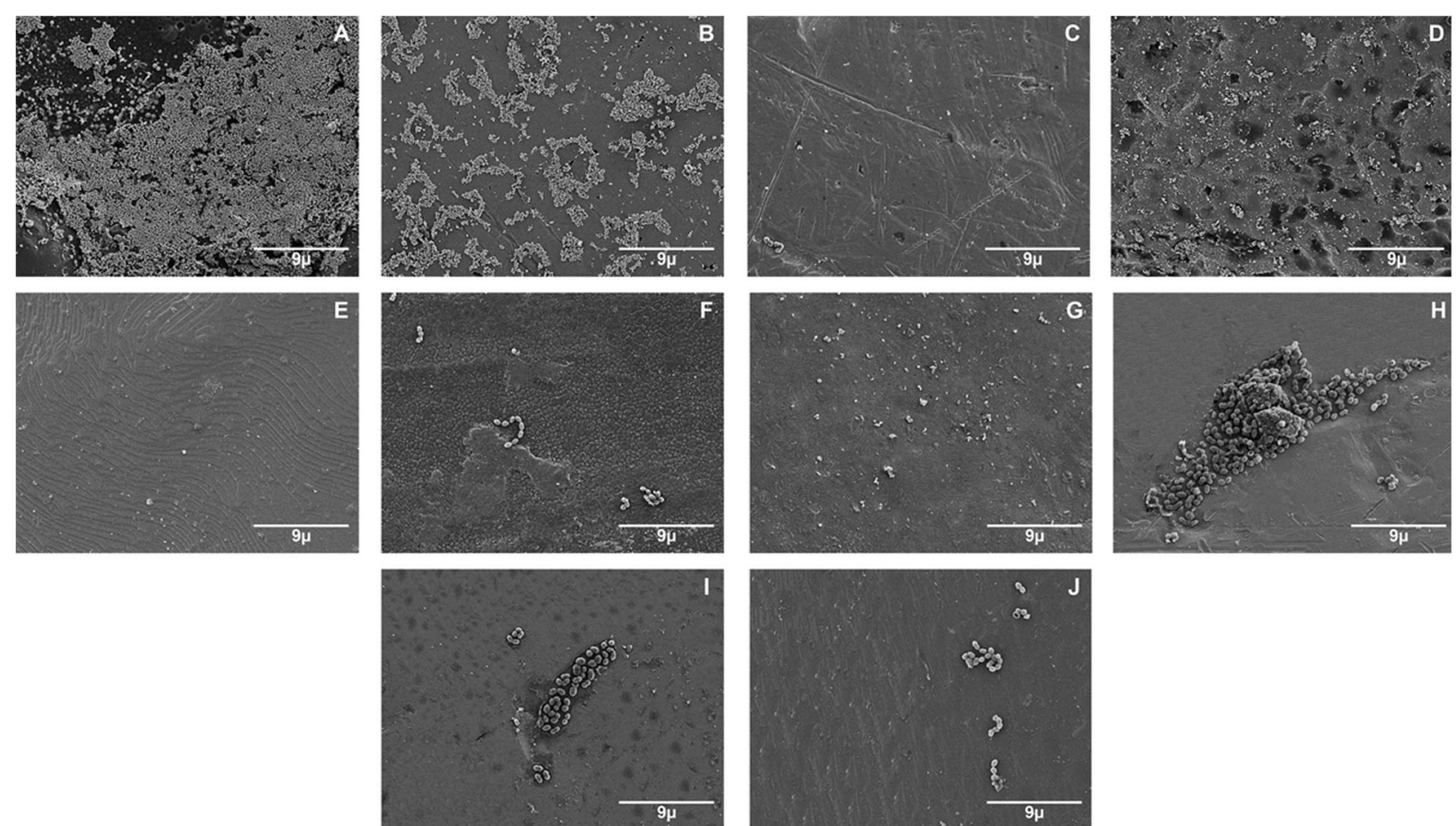

Fig. 2 Representative images from SEM of orthodontic brackets exposed to S.sobrinus (×2500). a Gln. b Glln. c Gllln. d GIVn. e GVn. f GVI. g GVII. h GVIII. i GIX. j GX

esthetics during orthodontic treatment, the purpose of this study was to identify possible variations in the adhesion patterns of $S$. mutans and S. sobrinus on different bracket materials to decrease the risk of possible side effects, such as the development of white spot lesions.

The results showed a significant difference in the level of adhesion between both bacterial species (Tables 1 and 2). In general, adhesion to the materials tested was greater for Streptococcus sobrinus than for Streptococcus mutans. This differs in a previous study, which reported that $S$. mutans have more adherence to orthodontic brackets than S. sobrinus and that each species of cariogenic streptococci has a characteristic level of adhesion [37].

Velázquez et al. reported in their study the bacterial adhesion to different types of orthodontic composites, these resins retain biofilm, and the finding that the Blugloo resin of the Ormco brand obtained the highest level of bacterial adhesion and that $S$. mutans and S. sobrinus can generate the higher risk of white spot injury [18].

The bacterial adhesion of S. mutans and S. sobrinus to orthodontic attachments is caused by Van der Waals forces, electrostatic and hydrophobic interaction, also it has been reported that the adhesion of cariogenic streptococcus to orthodontic attachments, such as orthodontic composites, elastomeric chains, and brackets, is caused by their manufacturing materials and their complex design. These can retain more amount of biofilm that is highly colonized by $S$. mutans and $S$. sobrinus around the fixed appliances and can proliferate on tooth surfaces and develop dental caries. This study was set to accurately determine the level of $S$. mutans and $S$. sobrinus that adhere to the orthodontic brackets. When cultured and tested independently, it is seen that both microorganisms are directly related to dental caries and also are the biggest acid producer, which causes demineralization [36].

In recent studies, surface modification of stainless steel orthodontic and NiTi alloy wires with AgNPs has led to antibacterial positive results against Lactobacillus acidophilus: an in vitro study [12].

Moreover, Eliades et al. [3, 19] identified stainless steel as a surface material with an increased potential for microbial attachment after measuring the free surface energy and the work of adhesion of raw materials and compared it with polycarbonate and ceramic materials. In contrast, results from Fournier et al. $[3,20]$ indicate weaker in vitro affinity of $S$. mutans for metallic brackets than for plastic brackets, which is in accordance with the results of a study conducted by Ahn et al. [2], who made multiple in vitro comparisons of cariogenic adhesion amounts on stainless steel, plastic, ceramic, and titanium brackets. Besides significant differences in the adhesion pattern of different cariogenic strains, their results showed higher adherence of cariogenic streptococci on plastic brackets than that in the four other types of brackets. 
For this research, the samples were not coated with saliva because previous studies [2, 37] have described that saliva coating does not significantly modify the adhesion of $S$. mutans and $S$. sobrinus. This report is similar to other investigations, which show that the saliva coating does not significantly alter the adhesion of Streptococcus in the underlying materials [36, 38].

Orthodontics is one of the treatments most requested by patients; however, as mentioned above, because of the complexity of its attachments, it generates more bacterial colonization and development of white spot lesions. Fluor has been used as a preventive method, but it has not been enough to avoid its occurrence [39, 40]. For this reason, at present, it is necessary to incorporate antibacterial substances, such as silver, making use of nanotechnology. Nanotechnology has been widely used for biomedical purposes, ranging from diagnosis, treatment, medication administration, to the coating of medical devices and personal health care. With the increased application of NPs in the medical context, it is necessary to have a better understanding of the mechanisms of NPs biological interactions and their potential toxicity, as well as the unique physiochemical properties of NPs, such as antibacterial, antifungal, antiviral, and anti-inflammatory activity [14].

The nanoparticles of metals, such as silver, copper, gold, titanium, and zinc, have gained significant interest in the recent years because of their remarkable antibacterial properties and because each has different properties and activation spectrum. For many years, silver has been employed as a bacteriostatic agent, so it was found to be a versatile application in the care of human health.

Silver nanoparticles are nanostructured materials whose base is silver salts. It has different biomedical applications because of its high antibacterial effect, aside from producing null toxicity in human tissues when used in low concentrations, which is why it is widely used in medical areas, such as covering materials, wound dressings, bone cement, food supplements, catheters, and in dentistry, they are used in some dental materials, such as pastes, cement, adhesives, resins, and dental implants [14].

The antibacterial effect of these nanostructured agents is attributed to the high surface area of the nanoparticles, which allows the greater presence of atoms on the surface, providing maximum contact with the environment [41]. Furthermore, Garcia and colleagues report in their study that the small size of these particles makes penetration through cell membranes easier (inhibiting ADN synthesis) [38]. Studies show that the positive charges of metal ions are critical for the antibacterial activity, allowing electrostatic action between the negative charge of the cell membrane of the bacteria and the positive charge of the nanoparticles [14, 41].

Different synthetic AgNPs routes lead to variable sizes, shapes, morphology, and even stability. Generally, these methods can be classified into three broad categories: physical, chemical, and biological (or green) syntheses.

The chemical method used in this research was suggested by Tanusheree Bala in their report [42]. Also, the use of equipment and methodology, such as the automatic sample combustion machine and the liquid scintillation counter device for measuring ${ }^{3} \mathrm{H}$, which are amply described by Saku et al. [33], and Nagayama et al. [34], as well as the results expressed and recorded in dpm. In this sense, a higher value of dpm means higher radioactivity, and therefore, higher adherence of a radiolabeled microorganism is found. In contrast, lower values of dpm indicate lesser adherence of the radiolabeled microorganism.

The results (Tables 1 and 2) in this study showed that the adherence of $S$. mutans and $S$. sobrinus radiolabeled to orthodontic brackets were significantly different between groups for both microorganisms $(p \leq 0.05)$. In general, the cariogenic streptococcus adhered to the orthodontic brackets with silver nanoparticles significantly less than to the bracket without silver nanoparticles. Group GIIIn (563.01 dpm) for S. mutans and group GIIIn (1044.08 $\mathrm{dpm}$ ) for $S$. sobrinus have the lowest bacterial adherence for both microorganisms. In the same mode, group GVI $(3153.83 \mathrm{dpm})$ and group GIX $(8197.32 \mathrm{dpm})$ had the highest bacterial adherence. In general, the level of bacterial adhesion to the materials tested was greater for $S$. sobrinus than that for $S$. mutans.

It is also important to remark that group GIIIn (Gemini Roth) showed the lowest bacterial adherence for both microorganisms, it is suggested that this may be caused by several factors. First, this group, in specific, as it can be observed in the images of the SEM, presents a smoother surface, with a better finish, the rough surface increases the surface area and niches, which are suitable environments for bacterial adhesión [43]. In addition, the literature reports that the positive charges of the metal ions repel the negative charges of the bacterial membrane. This could be due to the highest coaggregation of AgNPs that is why it has the highest antibacterial potential, and its significant reduction of microorganism adhesion has become an excellent option for orthodontic treatments with a wide possibility of avoiding dental caries and also the development of white spot lesion.

\section{Conclusions}

1. The silver coating decreased the adhesion of both $S$. mutans and S. Sobrinus to the orthodontic brackets, which demonstrates their antibacterial properties.

2. The modification of the surface of orthodontic brackets with silver nanoparticles can modify to prevent the development of dental plaque and dental caries during orthodontic treatment. 


\section{Abbreviations}

WHO: World Health Organization; AgNPs: Silver nanoparticles; $S$. mutans: Streptococcus mutans; S. sobrinus: Streptococcus sobrinus; ANOVA: Analysis of variance; NPs: Nanoparticles

\section{Acknowledgements}

The authors thank the Asahi University in Japan for providing support and infrastructure for making this research possible and the Mexican Council of Science and Technology (CONACYT).

\section{Authors' contributions}

IJR: Design of the work. Principal Author. RAML: Training and supervision in sample preparation, incorporation, synthesis and characterization of AgNPs. RY and TS: Training and supervision in bacteriological tests and the use of radiolabels. IJR and UVE: Analysis interpretation of data in the work. IJR, UVE, and RJSV: Drafted the work or substantively revised it. UVE, RJSV, and RAML: Approved the submitted version of this research. All authors read and approved the final manuscript.

\section{Funding}

Not applicable

\section{Availability of data and materials}

The datasets used and/or analyzed during the current study are available from the corresponding author on reasonable request.

All data generated or analyzed during this study are included in this published article (and its supplementary information files).

\section{Ethics approval and consent to participate}

Not applicable

\section{Consent for publication}

All authors approved the final manuscript.

\section{Competing interests}

The authors declare that they have no competing interests.

\section{Author details}

'Department of Health Sciences, School of Nursing, Autonomous University State of Mexico, Paseo Tollocan S/N, esq. Jesús Carranza, Moderna de la Cruz, 50180 Toluca City, México. ${ }^{2}$ Department of Orthodontics, School of Dentistry, Autonomous University State of Mexico, Paseo Tollocan esq. Jesús Carranza S/N, Universidad, 50130 Toluca City, México. ${ }^{3}$ Department of Nanomaterials, Sustainable Chemistry Research Center/National Autonomous University of Mexico, Highway Km. 14.5, Unidad San Cayetano, Toluca - Atlacomulco, 50200 Toluca City, México. ${ }^{4}$ Department of Prosthodontics, School of Dentistry, Asahi University, 1851 Hozumi, Gifu 501-0296, Japan. ${ }^{5}$ Research Institute of Radioisotope, School of Dentistry, Asahi University, 1851 Hozumi, Gifu 501-0296, Japan.

Received: 11 February 2020 Accepted: 8 June 2020

Published online: 17 August 2020

\section{References}

1. Papaioannou W, Gizani S, Nassika M, Kontou E, Nakou M. Adhesion of Streptococcus mutans to different types of brackets. Angle Orthod. 2007;6:77.

2. Ahn SJ, Lee SJ, Lim BS, Nahm DS. Quantitative determination of adhesion patterns of cariogenic streptococci to various orthodontic brackets. Am J Orthod Dentofac Orthop. 2007;132:815-21.

3. Jurela J, Repic D, Pejda S, Juric H, Vidakovic R, Matic I, et al. The effect of two different bracket types on the salivary levels of S mutans and S sobrinus in the early phase of orthodontic treatment. Angle Orthod. 2013;1:83.

4. Ogaard B, Rolla G, Arends J. Orthodontic appliances and enamel desmineralization. Part 1. Lesion development. Am J Orthod Dentofac Orthop. 1988:94:68-73.

5. Velazquez-Enriquez U, Scougall-Vilchis RJ, Contreras-Bulnes R, Flores-Estrada J, Uematsu S, Yamaguchi R. Adhesion of streptococci to various orthodontic composite resins. Aust Dent J. 2012;57:464-9.
6. Salehi P, Babanouri N, Roein-Peikar M, et al. Long-term antimicrobial assessment of orthodontic brackets coated with nitrogen-doped titanium dioxide against Streptococcus mutans. Prog Orthod. 2018;19:35.

7. Lucchese A, Gherlone E. Prevalence of white-spot lesions before and during orthodontic treatment with fixed appliances. Eur J Orthod. 2013;35:664-8.

8. The World Health Organization. Dental Caries (2012). [cited 14 June 2017]. Available from: http://www.who.int/mediacentre/factsheets/fs318/es/. (14 June 2017, date last accessed).

9. Mattingly JA, Sauer GJ, Yancey JM. Enhancement of Streptococcus mutans colonization by direct bonded orthodontic appliances. J Dent Res. 1983;62: 1209-11.

10. Sinclair PM, Berry CW, Bennett CL. Changes in gingiva and gingival flora with bonding and banding. Angle Orthod. 1987;57:271-8.

11. Freitas $A O$, Marquezan M, Nojima MC. The influence of orthodontic fixed appliances on the oral microbiota: a systematic review. Dental Press J Orthod. 2014;19:46-55.

12. Mhaske AR, Shetty PC, Bhat NS. Antiadherent and antibacterial properties of stainless steel and NiTi orthodontic wires coated with silver against lactobacillus acidophilus--an in vitro study. Prog Orthod. 2015;16:40. https:// doi.org/10.1186/s40510-015-0110-0.

13. Ogaard B. Oral microbiological changes, long-term enamel alteration due to decalcification, and caries prophylactic aspects. Orthodontic materials. Scientific and clinical aspects 2001. Stuttgart: Thieme.

14. Ali B-f, Borzabadi E, Lynch E. Nanoparticles in orthodontics, a review of antimicrobial and anti-caries applications. Acta Odontol Scand. 2014;72: $413-7$

15. Gorelick L, Geiger AM, Gwinnett AJ. Incidence of white spot formation after bonding and banding. Am J Orthod. 1982;81:93-8.

16. Bock NC, Seibold L, Heumann C, Gnandt E, Röder M, Ruf S. Changes in white spot lesions following post-orthodontic weekly application of 1.25 per cent fluoride gel over 6 months - a randomized placebo-controlled clinical trial. Part I: photographic data evaluation. European Journal of Orthodontics. 2017;39:134-43

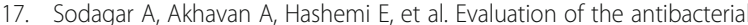
activity of a conventional orthodontic composite containing silver/ hydroxyapatite nanoparticles. Prog Orthod. 2016;17:40.

18. Velazquez-Enriquez U, et al. Quantitative analysis of S. mutans and S. sobrinus cultivated independently and adhered to polished orthodontic composite resins. J. Appl. Oral Sci. 2012;20:544-9.

19. Eliades T, Eliades G, Brantley WA. Microbial attachment on orthodontic appliances: I. wettability and early pellicle formation on bracket materials. Am J Orthod Dentofac Orthop. 1995;99:351-75.

20. Fournier A, Payant L, Bouclin R. Adherence of Streptococcus mutans to orthodontic brackets. Am J Orthod Dentofac Orthop. 1998;114:414-7.

21. Alexander JW. History of the medical use of silver. Surg Infect. 2009:10:289-92.

22. Shinonaga Y, Arita K. Antibacterial effect of acrylic dental devices after surface modification by fluorine and silver dual-ion implantation. Acta Biomater. 2012;8:1388-93.

23. Vlachou E, Chipp E, Shale E, Wilson YT, Papini R, Moiemen NS. The safety of nanocrystalline silver dressings on burns: a study of systemic silver absorption. Burns. 2007:33:979-85.

24. Gonzalez-Perez JC, Scougall-Vilchis RJ, Contreras-Bulnes R, De La RosaGómez I, Uematsu S, Yamaguchi R. Adherence of Streptococcus mutans to orthodontic band cements. Aust Dent J. 2012;57:464-9.

25. Douglas RM, Luiz FG, Aline ST, Adhemar CR, Emerson RC, Debora BB. The growing importance of material that prevent microbial adhesion: antimicrobial effect of medical devices containing silver. Int J Antimicrob Agents. 2009;34:103-10.

26. Djokic SS, Burrell RE. Behavior of silver in physiologic solutions. J Electrochem Soc. 1998;145:1426-30

27. Ogaard B, Rolla G, Arends J, Ten Cate JM. Orthodontic appliances and enamel demineralization. Part 2. Prevention and treatment of lesions. Am J Orthod Dentofac Orthop. 1988;94:123-8.

28. Rai M, Yadav A, Gade A. Silver nanoparticles as a new generation of antimicrobials. Biotechnol Adv. 2009;27:76-83.

29. Ogaard B, Rezk-Lega F, Ruben J, Arends J. Cariostatic effect and fluoride release from a visible light-curing adhesive for bonding of orthodontic brackets. Am J Orthod Dentofac Orthop. 1992;101:303-7.

30. Farhadian N, Miresmaeili A, Eslami B, Mehrabi S. Effect of fluoride varnish on enamel demineralization around brackets: an in-vivo study. Am J Orthod Dentofac Orthop. 2008;133:95-8. 
31. Chwalibog A, Sawosz E, Hotowy A, Szeliga J, Mitura S, Mitura K, et al. Visualization of interaction between inorganic nanoparticles and bacteria or fungi. Int J Nanomedicine. 2010;5:1085-94.

32. Ahn SJ, Lim BS, Yang HC, Chang YI. Quantitative analysis of the adhesion of cariogenic streptococci to orthodontic metal brackets. Angle Orthod. 2005; 75:666-71.

33. Saku S, Kotake H, Scougall-Vilchis RJ, et al. Antibacterial activity of composite resin with glass-ionomer filler particles. Dent Mater J. 2010;29:193-8.

34. Nagayama M, Sato M, Yamaguchi R, Tokuda C, Takeuchi H. Evaluation of coaggregation among Streptococcus mitis, fusobacterium nucleatum and porphyromonas gigivalis. Lett Appl Microbiol. 2001;33:122-5.

35. Hulsen W. A completely automatic sample combustion device for the technic of measuring $\mathrm{H}-3$ and $\mathrm{C}-14$ in the liquid scintillation spectrometer. Experientia. 1970;26:1406-7.

36. Ahn SJ, Kho HS, Lee SW, Nahm DS. Roles of salivary proteins in the adherence of oral streptococci to orthodontic brackets. J Dent Res. 2002;81:411-5.

37. Scougall-Vilchis RJ, Yamamoto S, Kitai N, Hotta M, Yamamoto K. Shear bond strength of a new fluoride-releasing orthodontic adhesive. Dent Mater J. 2007;26:45-51.

38. Garcia Contreras R, Argueta-Figueroa L, Mejía-Rubalcava C, Jimenez Martínez R, Cuevas-Guajardo S, Sanchez-Reyna PA, et al. Perspectives for the use of silver nanoparticles in dental practice. Int Dent J. 2011:61:297-301.

39. Artun J, Brobakken BO. Prevalence of caries and white spots after orthodontic treatment with multibonded appliances. Eur J Orthod. 1986;8:229-34.

40. Rosenbloom RG, Tinanoff N. Salivary Streptococcus mutans levels in patients before, during, and after orthodontic treatment. Am J Orthod Dentofac Orthop. 1991;100:35-7.

41. Sung J, Kuk E, Yu K, Kim J, Park S, Lee H, et al. Antimicrobial effects of silver nanoparticles. Nanomedicine. 2007;3:95-101.

42. Bala T, Armstrong G, Laffir F, Thornton R. "Titania-silver and alumina-silver composite nanoparticles: novel, versatile synthesis, reaction mechanism and potential antimicrobial application" en J colloid and. Interface Science. 2011; 356:395-403.

43. Quirynen $M$, Marechal $M$, Busscher HJ, Weerkamp AH, Darius PL, Van Steenberghe $D$. The influence of surface free energy and surface roughness on early plaque formation, an in vivo study in man. J Clin Periodontol. 1990; 17:138-44.

\section{Publisher's Note}

Springer Nature remains neutral with regard to jurisdictional claims in published maps and institutional affiliations.

\section{Submit your manuscript to a SpringerOpen ${ }^{\circ}$ journal and benefit from:}

- Convenient online submission

- Rigorous peer review

- Open access: articles freely available online

- High visibility within the field

- Retaining the copyright to your article

Submit your next manuscript at $\boldsymbol{\nabla}$ springeropen.com 